\title{
Robust Method for Diagnosis and Detection of Faults in Photovoltaic Systems Using Artificial Neural Networks
}

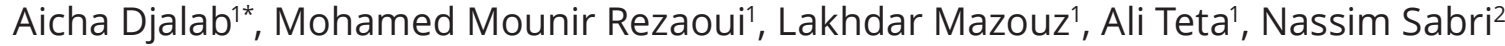 \\ ${ }^{1}$ Department of Electrical Engineering, Faculty of Technology, University of Djelfa, P. O. B. 3117, Djelfa, Algeria \\ 2 Department of Electrical Engineering, Faculty of Technology, University of Medea, 26000 Medea, Algeria \\ * Corresponding author, e-mail: d.aicha1@yahoo.fr
}

Received: 10 August 2019, Accepted: 03 December 2019, Published online: 12 March 2020

\begin{abstract}
During their operation, PV systems can be subject of various faults and anomalies that could lead to a reduction in the effectiveness and the profitability of the PV systems. These faults can crash, cause a fire or stop the whole system. The main objective of this work is to present a sophisticated method based on artificial neural networks ANN for diagnosing; detecting and precisely classifying the fault in the solar panels in order to avoid a fall in the production and performance of the photovoltaic system. The work established in this paper intends in first place to propose a method to detect possible various faults in PV module using the Multilayer Perceptron (MLP) ANN network. The developed artificial neural network requires a large database and periodic training to evaluate the output parameters with good accuracy. To evaluate the accuracy and the performance of the proposed approach, a comparison is carried out with the classic method (the method of thresholding). To test the effectiveness of the proposed approach in detecting and classifying different faults, an extensive simulation is carried out using Matlab SIMULINK.
\end{abstract}

Keywords

photovoltaic system, diagnosis, faults detection, method of thresholding, artificial neural networks

\section{Introduction}

Today electrical energy production covers a very important part in the world due to the energy needs of the industrialized societies that increase regularly. On the other hand, developing countries will need more and more energy to complete their development. Large parts of their production of energy are from fossil fuels. However, these sources have crucial disadvantage such as gas emissions, thus an increase in pollution; more the additional dangers of excessive consumption of natural resources stock, reducing the reserves of this type of energy in a dangerous way for nature in the future [1].

Renewable energy means the energy of the sun, the wind, the heat of the earth, water or biomass, which are considered as sources of clean alternative energy. The direct exploitation of solar energy using sensors is based on two distinct technologies: one produces calories, and one thermal energy, the other produces solar electricity, which is the subject of this article.

Solar energy comes directly from the sunlight. The sun is a constant source of energy and available worldwide.
The interest in PhotoVoltaic (PV) systems has grown rapidly over the last decade because of many advantages: it is a global power source, pollution-free, noise-free, easy to install, it is possible to convert installed and / or incorporated into buildings. As a result, the number and size of PV (PVS) systems has rapidly increased worldwide. The photovoltaic market grew by $97.9 \mathrm{GW}$ in 2018, while total capacity reached $402.5 \mathrm{GW}$ worldwide [2]. In reference to IRENA (International Renewable Energy Agency) [3], the price of photovoltaic modules fell by $83 \%$ between 2010 and 2017, and the real cost is less than 0.10 USD / Wp [3, 4]. During the operation of the PhotoVoltaic (PV) system, these cells may get disturbances due to exposure to external atmospheric factors or various internal failures, which affects the stability of the system and reduces their efficiency and production yield. Efficient and accurate detection of PV system faults can protect the system against downtime or collapse, while improving the efficiency of the PV system, ensuring safe operation and reducing power generation costs. Hence, the development of diagnostic 
methods for fault detection in the behavior of PV systems is particularly important and necessary because of the expansion degree of PV systems and the need to optimize their reliability and performance.

Many techniques have been developed for the possible detection of failures in PV systems: Techniques for grid-connected PV systems fault detection. Some of these techniques use meteorological and satellite data to predict defects in GCPV installations [5, 6]. However, some PV fault detection algorithms do not require climate data (solar irradiance and module temperature) such as the earth capacitance measurements established by Takashima et al. [7]. In addition, the detection of hot spots in PV substrings using the characterization of AC parameters is developed by Kim et al. [8]. Obi and Bass [9] and Khamis et al. [10] present a comprehensive analysis of the faults, trends and challenges of the grid-connected PV systems. Other PV fault detection approaches use statistical analysis techniques to identify micro-cracks and their impact on PV output power as presented by Dhimish et al. [11]. However, Zhao in [12] develops a Decision Tree technique (DT) to examine two different types of faults using an Over Current Protection Device (OVPD). In [13], the authors present an improved reliability of photovoltaic systems through a real-time Field Programmable Gate Array (FPGA) based on switch fault diagnostics and fault-tolerant DC-DC converters. Chong and Zhang [14] suggest a controller design for integrated PV conversion modules under partial shading conditions. a fault detection method based on the ratio between the DC side and the $\mathrm{AC}$ side of the photovoltaic system by Chine et al. [15] presents a method can detect five different faults, such as faulty modules in a PV array, a faulty DC / AC inverter, and defective Maximum Power Point Tracking (MPPT) units.

Other methods of PV fault detection are based on the comparison of simulated and measured efficiencies by analyzing losses on the DC side of the GCPV [16, 17]. In addition, Silvestre et al. [18] offers a new defect detection procedure in GCPV systems, based on the evaluation of current and voltage indicators. The main advantage of this algorithm is to reduce the number of monitoring sensors in photovoltaic systems and integrate a fault detection algorithm into an inverter without using simulation software or additional external hardware devices. On the other hand, another fault detection algorithms focus mainly on defects occurring on the PV systems, such as some faulty PV Modules and Partial shading affecting the PV system as proposed by Dhimish et al. [19]. The approach uses a mathematical analysis technique to identify failing conditions in DC / AC inverters. Boukenoui et al. [20] proposes a new intelligent MPPT method for autonomous photovoltaic systems operating under fast transient variations based on a fuzzy logic controller (FLC) with scanning and storage algorithm.

In addition, Mutlag et al. [21] present an adaptive FLC design technique for PV inverters using a differential search algorithm. N. Sa-ngawong and Ngamroo [22] propose smart photovoltaic parks for robust frequency stabilization in multi-zone interconnected power systems using Sugeno fuzzy logic control. A similar approach has been developed by Palaniswamy and Srinivasan [23] for power optimization in stand-alone photovoltaic systems.

In $[24,25]$, the authors use a fuzzy logic Mamdani classification system consisting of two inputs, the voltage / power ratio and a membership function at the output. The results can accurately detect several faults in the PV plant, such as partial shading and short circuit of photovoltaic modules.

Artificial Intelligent Networks (ANN) is another machine learning technique currently used to detect failures in PV systems. Yagi et al. [26] develops a learning method based on expert systems to identify two types of faults (due to the shading effect and the failure of the inverter). Whereas Chine et al. [27] proposes an ANN network detecting faults on the DC side of PV systems, including defective bypass diodes and defective PV modules in a PV string. Mellit et al. [28] show that ANN is a possible solution for modeling and estimating the output power of a GCPV system. However, Polo et al. [29] provide a prediction of the failure mode and energy recovery of photovoltaic installations to facilitate dynamic maintenance tasks using models based on the ANN model. Sepasi et al. [30] suggests continuing research on a very short-term load forecast for a high-penetration PV distribution system.

Finally, Amrouche and Le Pivert [31] proposes a daily local forecast based on a ANN network for Global Horizontal Irradiance (GHI). The ANN model is developed to predict the local GHI based on a daily weather forecast provided by the US National Oceanic and Atmospheric Administration (NOAA) for four neighboring sites.

The main contribution of this work is to propose a new technique based on Artificial Neural Network (ANN) for diagnosing and identifying faults in the PV model and extending its application to the PV system (offline and online detection). This technique is able to diagnose and identify faults that occur in: photovoltaic cells, PV modules and bypass diodes.

The proposed technique is based on the analysis of a set of output values (such as current, voltage and power) 
of the photovoltaic module, in case of normal operations (healthy) and defective operations. The analysis is performed using two different algorithms:

- Algorithm 1 implements the threshold approach signal and identifies the faults with a combination of different symptoms;

- Algorithm 2 consists of an ANN-based approach to identify faults with the same combination of symptoms.

The performances of the neural approach are analyzed on the basis of a comparison with the classical method of thresholding and with other papers [19, 27].

The rest of the paper is organized as the following: Firstly, it presents the mathematical model and the characteristics of the PV module then main types of faults occurring in the PV module. Next the proposed faults diagnosis technique is presented. Finally, simulation results, conclusion and future prospects are expressed.

\section{Modelling photovoltaic system}

A photovoltaic system consists of four blocks as shown in Fig. 1. The first block represents the energy source (photovoltaic panel), the second one is a DC-DC boost converter, the third one represents the load and the fourth block represents the MPPT command system "Perturbation and Observation". The main role of the static converter is to make an impedance matching so that the panel delivers the maximum energy.

\subsection{Photovoltaic cell model}

The basic element of a photovoltaic system is the photovoltaic cell. It composes the modules that are themselves assembled into panels. The panels generate electricity.

The most commonly used circuit model to describe the electrical behavior of a PV cell is the single diode model as shown in Fig. 2 [32, 33].

This model represents the solar cell as a current source that models the conversion of light flux into electrical

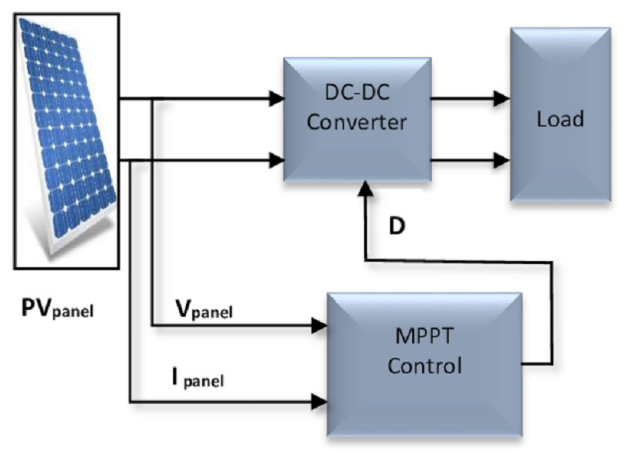

Fig. 1 Photovoltaic system energy. The $R_{s}$ series resistor represents the contact and connection resistance. Other resistor in parallel called the shunt resistor Rsh represents the leakage current. All parameters are cited in the nomenclature above.

From the equivalent circuit of Fig. 2, it can be written $[32,33]$ :

$I_{p h}=I_{d}+I_{s h}+I$.

The current in the diode $I_{d}$ is given by:

$I_{d}=I_{0}\left[\exp \left(\frac{V+R_{S} I}{V_{t} a}\right)-1\right]$.

The current in the $R_{s h}$ resistance is expressed by:

$I_{s h}=\left(\frac{V+R_{s} I}{R_{s h}}\right)$.

From Eq. (1), the expression of current is obtained by:

$I=I_{p h}-I_{d}-I_{s h}$.

Replacing Eq. (4) in Eqs. (2) and (3), the characteristic equation becomes:

$I=I_{p h}-I_{0}\left[\exp \left(\frac{V+R_{S} I}{V_{t} a}\right)-1\right]-\left(\frac{V+R_{S} I}{R_{s h}}\right)$.

Where $I_{p h}$ is the photo current, $I_{d}$ is the diode current, $I_{s h}$ is the current in shunt resistance, $I_{0}$ is the saturation current of the diode, $R_{s}$ is the resistance series cell, $R_{s h}$ is the shunt resistance cell, a is the diode quality (or ideality) factor and $V_{t}$ is the thermal voltage and it can be defined by:

$V_{t}=\frac{N_{s} K T}{q}$.

Where $N_{s}$ is the number of cells connected in series, $K$ is the Boltzmann constant $\left(1.3854^{*} 10-23 \mathrm{~J}^{\circ} \mathrm{K}-1\right)$, q is the electron's charge $\left(\mathrm{e}=1.6 * 10^{-19}{ }^{\circ} \mathrm{C}\right)$ and $\mathrm{T}$ is the temperature of the cell.

The efficiency: The efficiency of a photovoltaic cell is considered as a performance indicator, where, it is equal to

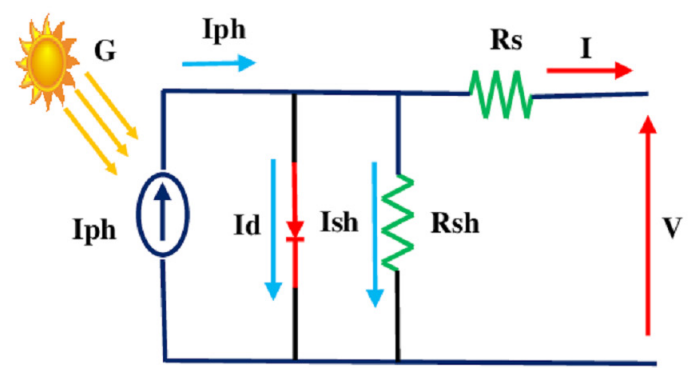

Fig. 2 Equivalent circuit of a solar cell 
the ratio between the maximum output power and the irradiation power received by the cell, which is defined as [34]:

$\eta_{P V}=\frac{I_{m p p} V_{m p p}}{S G}$.

Where $I_{m p p}, V_{m p p}$ are the current and voltage at the point of maximum power $M P P$, and the irradiation power corresponds to the product of the surface $S\left(\mathrm{~m}^{2}\right)$ of the cell by the irradiation $G$.

The performance factor: is the ratio between the efficiency $\eta_{\mathrm{Pv}}$ to the theoretical efficiency $\eta_{\mathrm{Th}}$ and it is defined as:

$C P=\frac{\eta_{P v}}{\eta_{T h}}$

The form factor: it allows judging the quality of a photovoltaic cell. It is defined as the ratio between the maximum power and the power at short-circuit current and open-circuit voltage [35]:

$F F=\frac{I_{m p p} V_{m p p}}{I_{s c} V_{o c}}$.

From this definition, for a cell whose $I_{s}-V_{s}$ characteristic is rectangular (current source), the form factor will therefore be unitary. The form factor of a good photovoltaic cell should be between 0.75 and 0.85 [36].

\subsection{Photovoltaic module characteristics}

In this work, the most common faults that occur in the photovoltaic module will be analyzed; a KC130GHT PV photovoltaic module, containing $36 \mathrm{PV}$ cells with a power rating of $130 \mathrm{~W}$ polycrystalline silicon is chosen. The features of this module are detailed in the Table $1[37,38]$.

Figs. 3 and 4 show the curves of the characteristics I(V) and $\mathrm{P}(\mathrm{V})$ in standard conditions $\left(\mathrm{E}=1000 \mathrm{~W} / \mathrm{m}^{2}, \mathrm{~T}=25^{\circ} \mathrm{C}\right)$. Under standard test conditions (STC: $\mathrm{G}=1000 \mathrm{~W} / \mathrm{m}^{2}$ and $\left.\mathrm{T}=25^{\circ} \mathrm{C}\right)$. The electrical characteristics $I-V$ and $P-V$ curve of the PV module are nonlinear characteristics and have only one maximum power point as shown in Fig. 3. This curve shows that the electrical output characteristics

Table 1 Electrical characteristics of the KC130GHT PV module

\begin{tabular}{lc}
\hline \multicolumn{2}{c}{ Electrical characteristics } \\
\hline Power at maximum power point $\left(P_{m p p}\right)$ & $130 \mathrm{~W}$ \\
Optimal operation voltage $\left(V_{m p p}\right)$ & $17.6 \mathrm{~V}$ \\
Current at maximum power point $\left(I_{m p p}\right)$ & $7.39 \mathrm{~A}$ \\
Open Circuit Voltage $\left(V_{o c}\right)$ & $21.9 \mathrm{~V}$ \\
Short Circuit Current $\left(I_{s c}\right)$ & $8.02 \mathrm{~A}$ \\
Number of cells connected in series & 36 \\
Number of cells connected in parallel & 1 \\
\hline
\end{tabular}

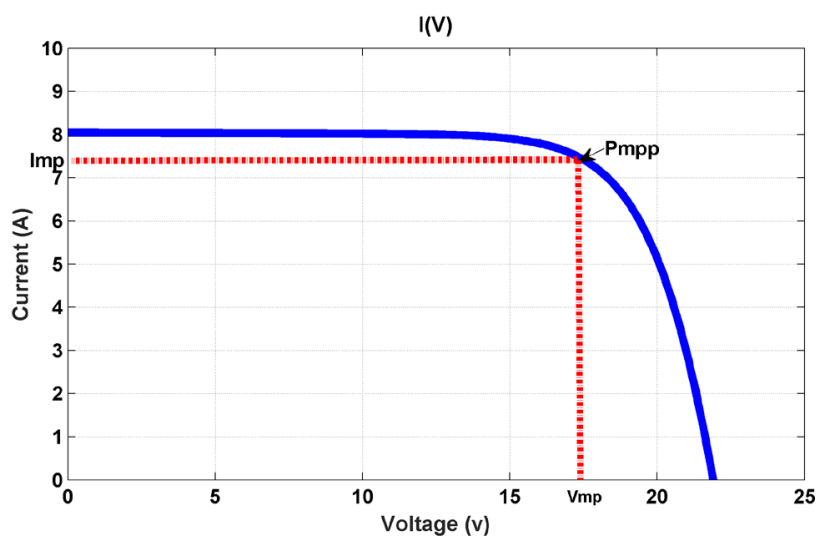

Fig. 3 I (V) Characteristic of a photovoltaic module under STC $\left(25^{\circ} \mathrm{C}\right.$ and $1000 \mathrm{~W} / \mathrm{m}^{2}$ )

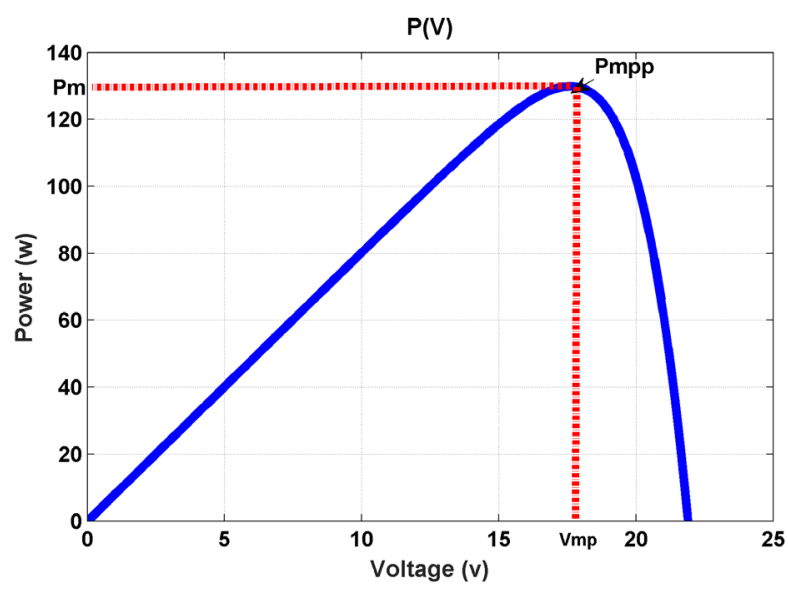

Fig. 4 P (V) Characteristic of a photovoltaic module under STC $\left(25^{\circ} \mathrm{C}\right.$ and $1000 \mathrm{~W} / \mathrm{m}^{2}$ )

of the simulated model are closed to electrical characteristics in the data sheet of the PV module.

This simulated curve shows the maximum power point by the data tips on the $I-V$ and $P-V$ curves, where $P_{\max }$ equals $129.9(\mathrm{~W}), V_{\text {max }}=17.55(\mathrm{~V})$ and $I_{\text {max }}=7.40(\mathrm{~A})$. In sum the $I-V$ and $P-V$ curves of the PV solar cell depend on the solar irradiance and the temperature of the PV solar cell.

\section{Faults in PV module}

The main faults that can occur in PV module usually affect a set of cells, modules, strings, and array. These faults may appear due to a manufacturing default or due to weather conditions [39], and both can lead to a decrease in PV system output power, efficiency, and reliability. Table 2 [4] arises the main faults that may occur in a PVS.

The following faults can be classified as: blocking, bypass and blocking diode faults, junction box faults, PV module faults, PV array, arc, earth and line-to-line faults [4].

The most common faults in the PV modules including diode bypass faults, short circuit cell fault, Open Circuit Fault and Mismatch Fault as shown in Figs. 5 to 9. 
Table 2 Many of different type of faults with connected information: affected components, causes and effects [4].

\begin{tabular}{|c|c|c|c|}
\hline Type of fault & Affected components & Causes & Effects \\
\hline Hot spot & Cells/Module & $\begin{array}{l}\text { - Soiling, dust, snow and shadow } \\
\text { - PV module of different classes or technology } \\
\text { - Fragmentation of cells } \\
\text { - Current mismatch between cells } \\
\text { - High resistance or "cold" solder points } \\
\text { - Aging and degradation of cells }\end{array}$ & $\begin{array}{l}\text { - Damage of solar cells. } \\
\text { - Open circuits. } \\
\text { - Reduce efficiency and } \\
\text { reliability. }\end{array}$ \\
\hline Diode faults & $\begin{array}{l}\text { Bypass diode or } \\
\text { blocking diode }\end{array}$ & $\begin{array}{l}\text { - Partially shaded cells } \\
\text { - Overheating }\end{array}$ & $\begin{array}{l}\text { - Damage diodes } \\
\text { - Short circuited diode, open } \\
\text { circuited or Shunted diode }\end{array}$ \\
\hline $\begin{array}{l}\text { PV module } \\
\text { fault and PV } \\
\text { array fault }\end{array}$ & PV module & $\begin{array}{l}\text { - Glass breakage of frameless PV module caused by the } \\
\text { clamps } \\
\text { - Connector failure (disconnection) } \\
\text { - } \text { Isolated from ground } \\
\text { - Wiring mistake at install fault }\end{array}$ & $\begin{array}{l}\text { - Shunted module } \\
\text { - Short circuit between PV } \\
\text { module } \\
\text { - Leakage currents within a PV } \\
\text { module } \\
\text { - Damage PV Module } \\
\text { - Reduce efficiency and } \\
\text { reliability } \\
\text { - Reduced output power }\end{array}$ \\
\hline Ground fault & PV Array or PV String & $\begin{array}{l}\text { - Insulation failure of cables } \\
\text { - Incidental short circuit between normal conductor and } \\
\text { ground } \\
\text { - Ground fault within PV module (Monitoring System) } \\
\text { cable insulation damage during the installation } \\
\text { - Ground fault within the PV module (Monitoring System) } \\
\text { (degraded sealant and water ingress) } \\
\text { - Insulation damage of cables. } \\
\text { - Accidental short circuit inside the PV combiner box. }\end{array}$ & - Risk of fire \\
\hline $\begin{array}{l}\text { Line-to-line } \\
\text { fault }\end{array}$ & PV Array & $\begin{array}{l}\text { - An unintentional low impedance current path between } \\
\text { two points. } \\
\text { - Insulation failure of cables } \\
\text { - Incidental short circuit between current carrying } \\
\text { conductors } \\
\text { - LLFs within the DC junction box. }\end{array}$ & $\begin{array}{l}\text { - } \text { Risk of fire } \\
\text { - Damage PVMs (Monitoring } \\
\text { System) }\end{array}$ \\
\hline
\end{tabular}

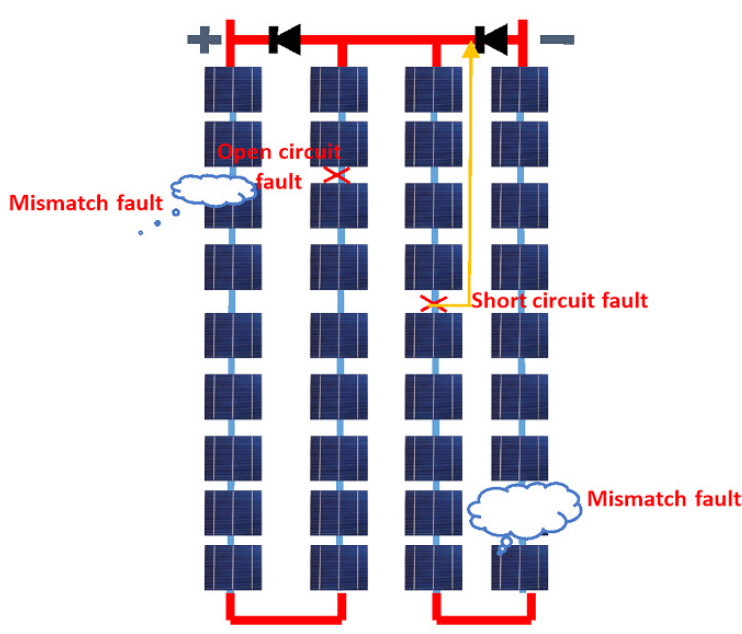

Fig. 5 Photovoltaic module KC 130 GHT with typical faults

Among the above-cited faults, nine faults on PV module are chosen to be investigated as listed in Table 3.

\subsection{The used diagnosing techniques}

In this part, two different methods of the faults detection are applied on a PV module, in which nine faults are
Table 3 Different type of faults occurring in the examined PV module

\begin{tabular}{ll}
\hline Symbol & Type of fault \\
\hline F1: & $\begin{array}{l}\text { shading of a single cell in Group } 1 \text { of the module at } 50 \% . \\
\text { (mismatch type) }\end{array}$ \\
F2: & $\begin{array}{l}\text { shading of a single cell in Group } 1 \text { of the module at } 100 \% \\
\text { (mismatch type) }\end{array}$ \\
F3: & $\begin{array}{l}\text { shading of a cell of the Group } 1 \text { and another of the Group } \\
2 \text { to } 50 \% \text { (mismatch type) }\end{array}$ \\
F4: & $\begin{array}{l}\text { shading of a cell of the Group } 1 \text { and another of the Group } \\
2 \text { to } 100 \% \text { (mismatch type) }\end{array}$ \\
F5: & $\begin{array}{l}\text { increase the resistance series }\left(R_{s}=1 \text { ohm) module. }\right. \\
\text { (mismatch type) }\end{array}$ \\
F6: & shorted cell $\left(R_{p}=0\right.$ ). (mismatch type) \\
F7: & shading of six cells with by-pass diode disconnected. \\
F8: & $\quad$ by-pass diode reversed. \\
F9: & defective bypass diode.
\end{tabular}

chosen, the first one is classical and based on the threshold detection of each subsequent symptom giving fault detection of binary indications; these residues have a theoretical value of zero for an ideal system and not zero otherwise [32], and a second method based on artificial neural networks. 


\subsection{Method based on threshold signal (algorithm 1)}

As a first step, the two PV modules (KC130GHT) system is simulated as shown in Fig. 6. These modules consist of 36 cells and each one is flawless to serve as a reference module while groups of 18 cells are equipped with a bypass diode. The other module is tested for different chosen faults. Its resulting $P-V$ and $I-V$ characteristics are compared later to that of the reference module. The simulations are performed using a MatLab / Simscape tool for a PV module consists of 36 solar cells connected in series.

A complete simulation of the different faults makes it possible to obtain different curves, as they are represented in (Figs. 9 (a) and (b)). From these figures three symptoms can be drawn in which it can be possible to distinguish the considered faults.

1. The symptom S1: presents the reduction of the power produced by the PV module.

2. The symptom S2: presents the open-circuit voltage reduction of the PV module.

3. The symptom S3: shows the short circuit current reduction of the PV module [39].

The second step consists in calculating the threshold of the residues:

The selected symptoms are calculated from a comparison between the $I-V$ characteristic of a PV system in normal operation and that in malfunctioning operation. The first characteristic is obtained from a model and serves as the reference $[36,37]$. The second characteristic is obtained from the measurement of the current system. From the measurement or the model, these two characteristics cause uncertainties in the generation of symptoms. These uncertainties produce non-zero amplitude for each symptom even if no defect appears.

From the standard IEC 61724 [40], that indicates a relative error of $1 \%, 1 \%$, and $2 \%$ while measuring current, voltage, and power, respectively. The model uncertainty is related to the manufacturing tolerance and sensors noise. The maximum error introduced by this uncertainty is calculated, according to [41], by adding a dispersion parameter to the simulation model parameters. The obtained relative errors associated to current, voltage, and power are equal to $5.0 \%, 3 \%$, and $6 \%$, respectively.

In the third step, a diagnostic algorithm is introduced to provide the specific indication to each fault of the nine selected faults. Fig. 6 illustrates block of the detection and fault diagnostic algorithm for a PV module by threshold (classical) method.

After this classification obtained by this method, four groups of faults can be attained:

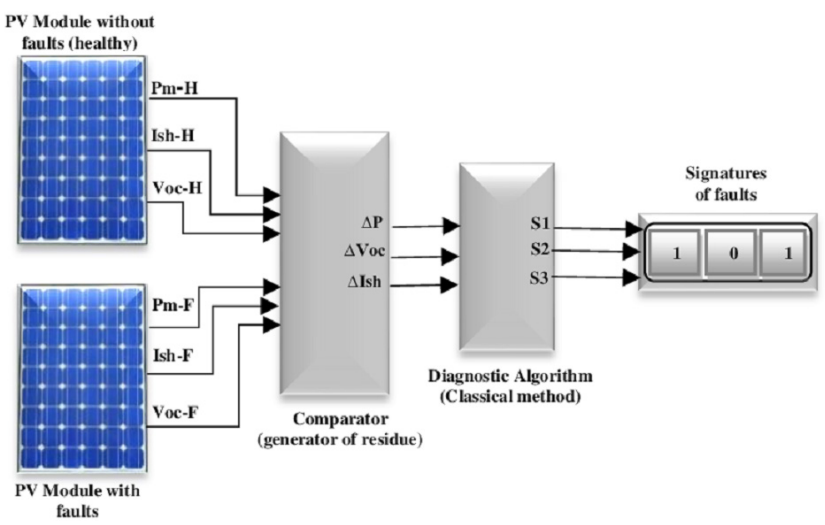

Fig. 6 Detection and fault diagnostic algorithm for a PV module by threshold (classical) method

- Group 1 (1 0 0): Partial shadow (50\%) 2 cells, $R_{s}$ fault, and Partial shadow (bypass diode is faulted): F1, F5, F7;

- Group 2 (1 1 0): A group of faults including F2, F6, $\mathrm{F} 8$ and $\mathrm{F} 9$.

- Group 3 (1 0 1): Partial shadow 2 cells (bypass diodes work correctly): F3;

- Group 4: (1 1 1): Partial shadow (bypass diodes work correctly): F4.

Referring to previous results, the first algorithm cannot distinguish the faults (F1, F5, and F7), and (F2, F6, F8 and F9), which have the same indications; on the other hand, the symptoms of the $I-V$ characteristic under these faults have different amplitudes at the same climatic conditions. Thus, to isolate these faults, a more efficient classification technique is needed, for such reason an ANN technique is chosen to be applied. The faults are then classified into two groups:

- Faults characterized by different indications. These faults are isolated using a threshold signal based approach.

- Faults with the same indication. These faults are isolated using an ANN-based approach.

The ANN model has been developed as follows:

- Selection of input and output variables;

- Standardization of data sets;

- Selection of the network structure;

- Network training;

- Network test.

\subsection{The Neural Networks Method (ANN)}

The Artificial Neural Network (ANN) is the system of adopting the physical implementation system to imitate the structure and function of human brain cells [42]. Nowadays, the ANN has been applied to various fields such as pattern recognition, signal processing, modeling and computer vision [43]. 
In this work, ANN is used as an identification tool for faults diagnosis in a photovoltaic module, where an MLP (multi-layer perception) feed forward neural network is used, in which it is characterized by one input layer, one output layer and one or more hidden layer [43]. For this MATLABbased model shown in Fig. 7 is exploited. The database of the artificial network is composed of the (Voltage, Current and the Power) of the PV module as inputs and the nine faults as outputs as well as the normal operation.

\subsubsection{Construction of the neural network}

To build the neural network, four main tasks must be realized: The construction of the ANN block, the acquisition of data (learning base), the classification of the various faults, and the network test [34]. Each neuron is connected to all the neurons of the next. Fig. 8 clearly shows that the Structure of ANN faults classification.

From Fig. 8, three layers can be seen:

- An input layer composed of three neurons, whose role is to transmit the values of the inputs that correspond to the variables $\left(P_{m}, V_{o c}\right.$ and $\left.I_{s h}\right)$ to the next layer called the hidden layer.

- A hidden layer contains ten neurons with selected sigmoid activation functions.

- An output layer composed of ten neurons, that indicate one of classes correspond to the faults F0 to F9 as well as the normal operation and the hidden layer

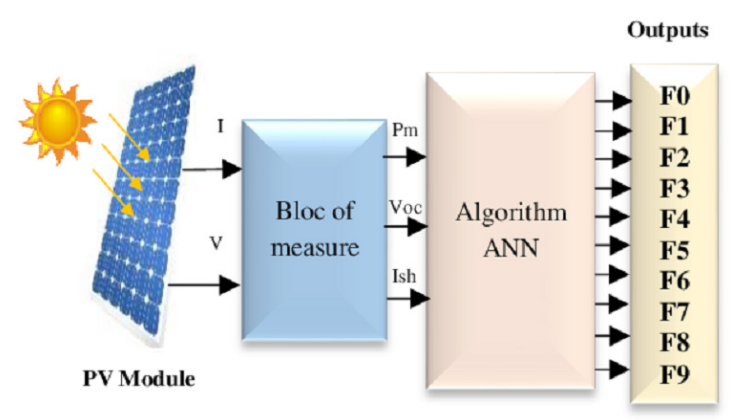

Fig. 7 The block of the fault detection system by ANN method

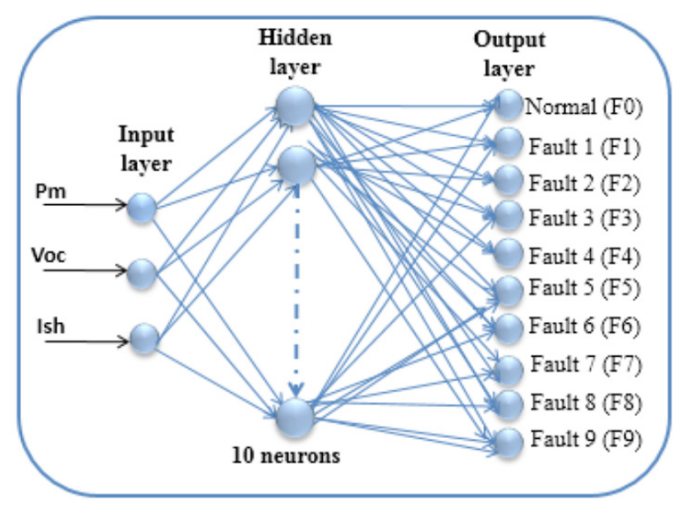

Fig. 8 Structure of ANN faults classification contains 10 neurons that has been obtained by the manner trial and error.

\section{Result and discussion}

This section presents the results of the Simscape based model as well as the performance of the proposed fault diagnosis technique for the PV module (KC130GHT) system is simulated, this module consists of 36 cells while groups of 18 cells are equipped with a bypass diode.

In this study, the impacts of different types of faults applied on a PV system in different aspects (variation of voltage or current, power losses) can be observed, and therefore different $I-V$ characterization curves are generated. Figs. 9 (a) and (b) show the curves for several typical types of faults. A fault of $R_{s h}$ and Bypass diode faults bring a reduced open circuit voltage $\left(V_{o c}\right)$ compared with the normal curve. While the mismatch fault (Partial shadow is used as an example in the case of study to cause a mismatch fault) which leads to a decrease in short circuit current $\left(I_{s c}\right)$ and this leads also to a decrease in power.

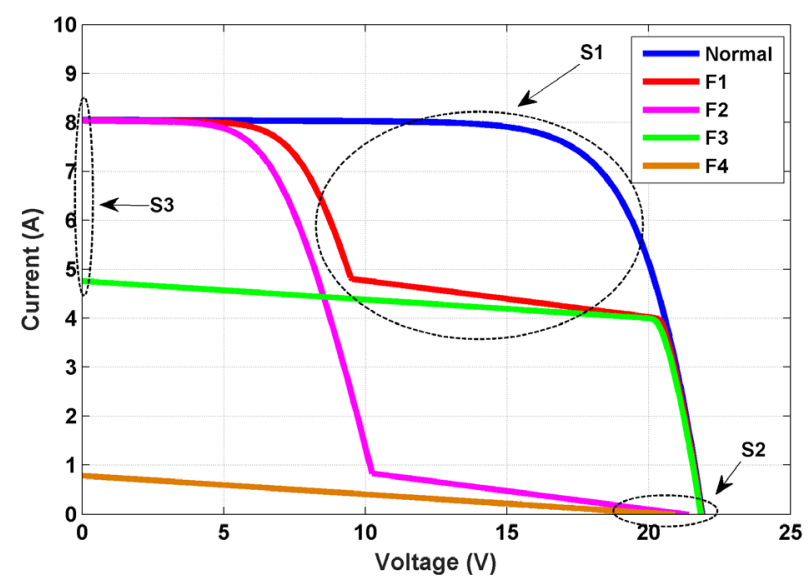

(a)

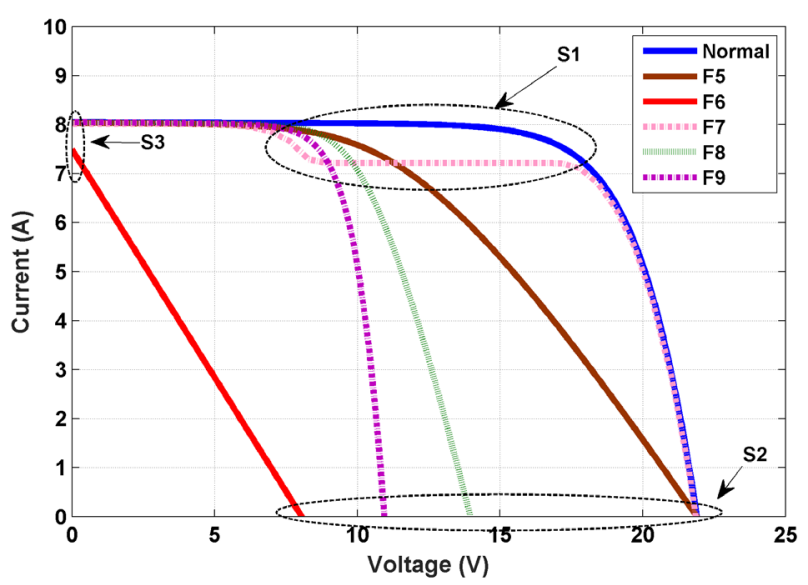

(b)

Fig. 9 (a), (b) I-V of PV Module in Different type of faults 


\subsection{Analysis of the applied diagnosis methods}

\subsubsection{Results of algorithm 1}

As aforementioned, the algorithm based on the threshold approach cannot distinguish all faults, where these faults: (F1, F5, and F7), and (F2, F6, F8 and F9) Have the same indications, on the other hand, the symptoms of property IV under these defects have different capacities under the same climatic conditions. Thus, to Solve this issue a more efficient method based on ANN is highly needed.

\subsubsection{Results of algorithm 2}

In our study, our network composed of three layers: An input layer, the next layer called hidden layer and the output layer, the hidden layer uses the tangent sigmoid transfer function (tansig), while the output layer uses the log-sigmoid transfer function (logsig), which has a binary output (it exists between ( 0 to 1$)$. It is easy to understand and apply), because the ANN in our context is used for classification purposes.

In this study, a data set of 65536 patterns has been generated using a MatLab/ Simscape ${ }^{\mathrm{TM}}$ simulation tool. the training of ANN is carried out using 52428 samples which represent $80 \%$ of total data, while a number of 13107 sample data is used for the test (equivalent of $20 \%$ of total data), the value of error goal is fixed to 0.001 which is sufficient to give good classification rate.

The convergence of the learning algorithm is verified by the learning curve given in Fig. 10 (a), where it can be seen that the value of the error objective is equal to 0.00994 at 41 iterations, the value is sufficient to give a good ranking rate.

This implies that the parameters of the network (weight and bias) are well determined.

To verify ANN's ability to classify faults, the dataset (training + test) is tested, in which the results of the classification are presented in Fig. 10 (b), where the green squares indicate correctly classified data and in the red squares indicate the opposite. The classification confusion matrix reveals that the correct and false classification rates obtained with the MLP-based model are $94.0 \%$ and $6.0 \%$, respectively, which reflects a good performance of the classification faults by the ANN model.

From Fig. 10 (b), the effectiveness of the ANN network can be analyzed in which this figure shows the output classification confusion matrices for the ANN networks. The cells of each matrix with red and green colors presents the percentage of faults correctly and not correctly classified by the ANN network respectively. Additionally, the gray blocks represent the total percentage of the detection accuracy in the column and row respectively.

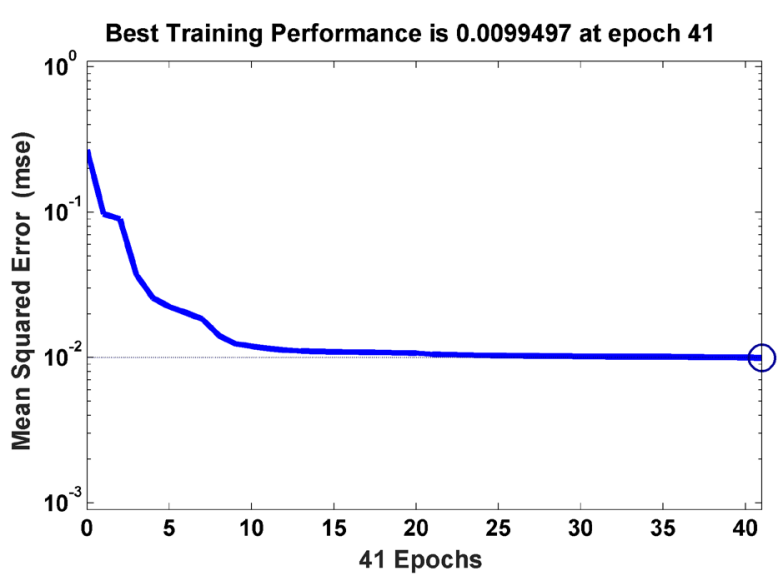

(a)

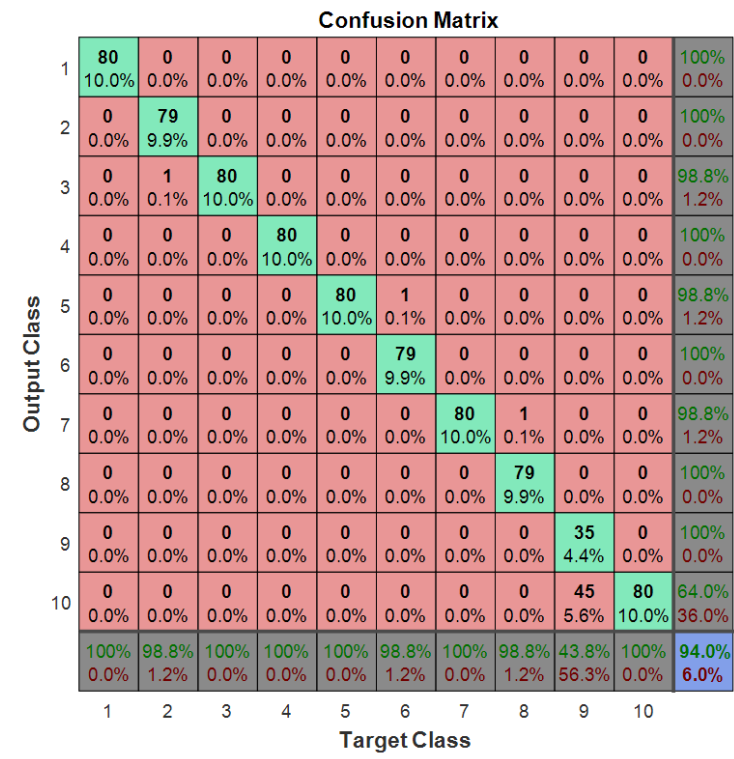

(b)

Fig. 10 (a) Learning curve of trained ANN. (b) Classification confusion matrix for ANN network

How to read the confusion matrices: the Fig. 10 (b) shows the confusion matrices in case for detection 9 faults. In this figure, the first nine diagonal cells show the number and percentage of correct classifications by the trained network. For example, 80 samples for F1 (fault type, shown in Table 3), are correctly classified. This corresponds to $10 \%$ of all tested samples (600 sample). Similarly, 79 samples are correctly classified as F2, this corresponds to $9.9 \%$ of all 600 samples. 80 samples are correctly classified as $\mathrm{F} 3$, this corresponds to $10 \%$ of all 600 samples.

In row 9 of Table 3, 45 sample is incorrectly classified as F9 and it is classified as F10, this corresponds to $5.6 \%$ of all 600 samples. For row 2, all samples have been classified correctly, $100 \%$. However, for column 2, out of 80 samples, $98.8 \%$ are correct and $1.2 \%$ are incorrect. 
The overall detection accuracy of the confusion matrix could be calculated using the diagonal cells as the following:

$1^{\text {st }}$ cell $(10.0 \%)+2^{\text {nd }}$ cell $(9.9 \%)+3^{\text {rd }}$ cell $(10.0 \%)+$ $4^{\text {th }}$ cell $(10.0 \%)+5^{\text {th }}$ cell $(10.0 \%)+6^{\text {th }}$ cell $(9.9 \%)+7^{\text {th }}$ cell $(10.0 \%)+8^{\text {th }}$ cell $(9.9 \%)+9^{\text {th }}$ cell $(4.4 \%)+10^{\text {th }}$ cell $(10.0 \%)=94.0 \%$

This 94.0 corresponds to the percentage of correctly classified samples (out of all tested samples, 600 samples). And $6.0 \%$ correspond to incorrectly classified samples.

In conclusion, the obtained results of this section shows that The overall detection accuracy of the network is $94.0 \%$ which means that the ANN network (that includes 3 inputs, 9 outputs with 1 hidden layer) detects accurately 564 samples out of 600 .

\subsection{Test on a PV system off-line and on-line}

In this section, our contribution is to expand this technique to be suitable for the fault diagnosis in the On-Line PV system. First step: a PV system consisting of 4 PV modules (KYOCERA 130 GHT) connected in series is modeled and simulated, where $P_{\max }$ equals $520(\mathrm{~W}), V_{o c}=87.6$ $(\mathrm{V})$ and $I_{s c}=8.02(\mathrm{~A})$. In the state of health and then four types of faults are created:

- F0: state without fault (healthy)

- F1: Increase the resistance series in one module (hot spot)

- F2: One module disconnected

- F3: One module disconnected Partial shadow of two modules (bypass diodes is faulted)

- F4: Partial shadow of two modules (bypass diodes work correctly).

This method is tested in state (off-line), after the same step for PV system on-line.

The curves in Fig. 11 are studied and analyzed the impact of the faults on the PV system. Next the new

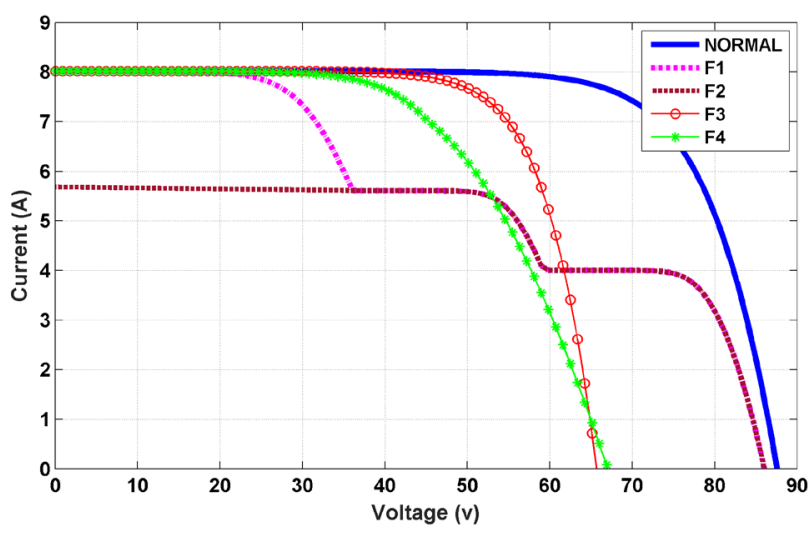

Fig. 11 I-V of PV system Off-Line in different type of faults technique (ANN) is tested in which the obtained results are in Fig. 12 (case 4 faults in PV system Online).

From Fig. 12 (a), the mean squared error is equal to 0.0067 at 60 epochs, the value is sufficient to give a good classification rate and the confusion matrix shows that the accuracy reaches the value of $97.2 \%$, which reflects a good performance of the classification faults by the ANN model.

Fig. 13 shows simulation results of diagnosis and detection of 4 different faults in a photovoltaic system (Online) by the ANN method, in which, in each step, the type of fault is well illustrated.

\section{Discussion}

In this study, artificial intelligent networks (ANN) have been developed for detecting faults in PV systems. This technique is used for detecting possible faults accruing in the used PV system.

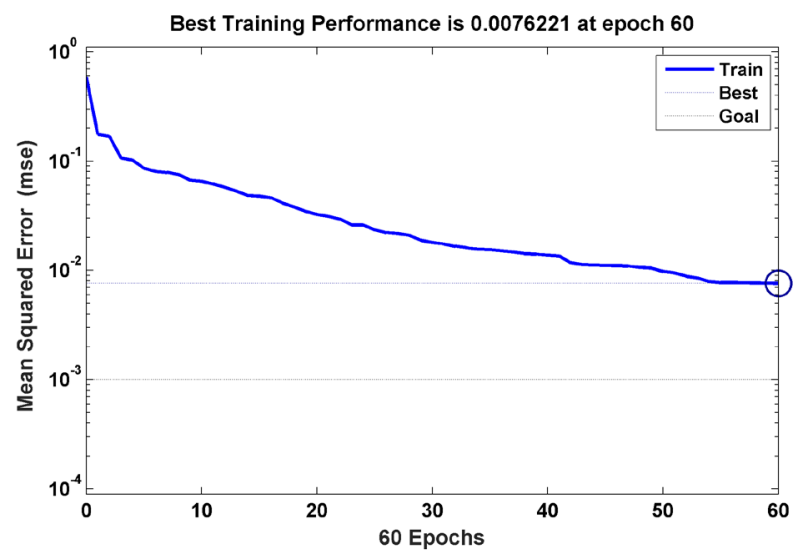

(a)

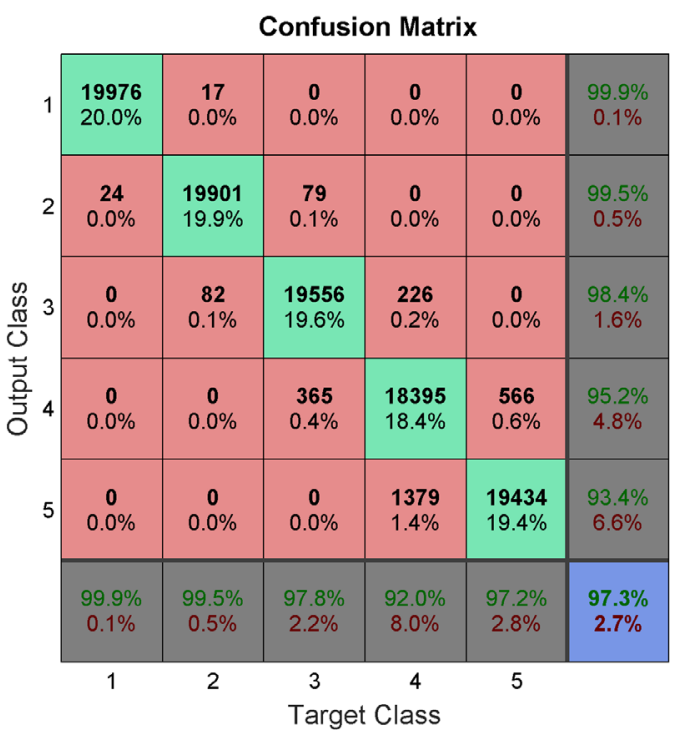

(b)

Fig. 12 (a) Learning curve of trained ANN; (b) Classification confusion matrix for ANN network (PV system on-line) 


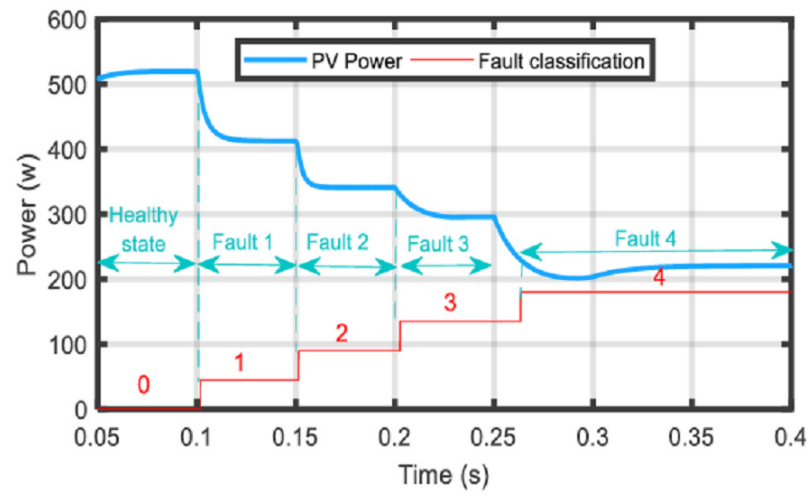

Fig. 13 The output power with 4 faults (diagnosis and detection by ANN in PVS online

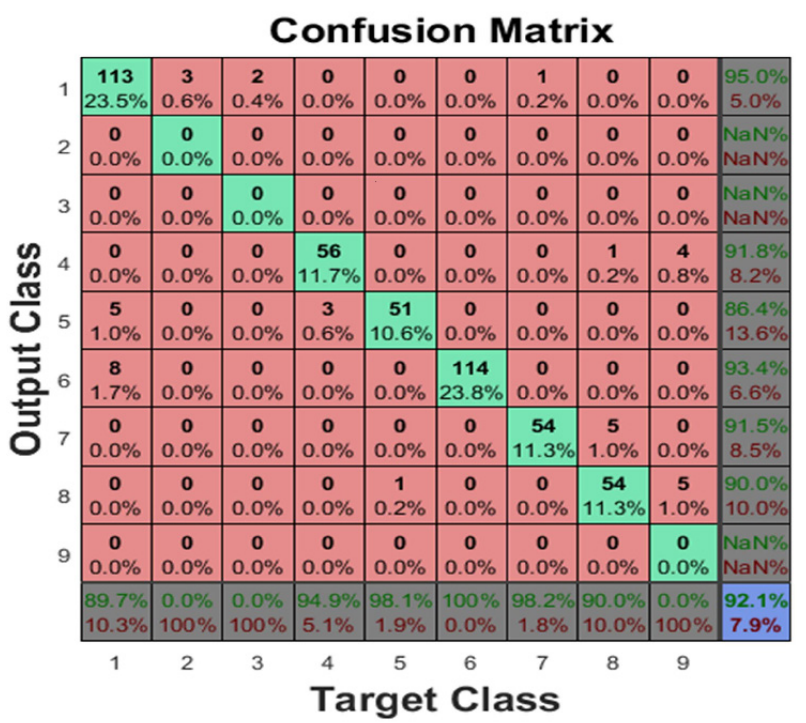

Fig. 14 Classification Confusion Matrix for ANN Network (case 9 faults). Results obtained by Dhimish et al. [19]

The mathematical modeling of the ANN network is much simple but it requires a lot of samples in order to validate the network.

From the obtained results in this paper, the overall detection accuracy of the network is $94.0 \%$ in the first case ( 9 faults) and $97.2 \%$ in the second case (5 faults).

In order to test the effectiveness of the final detection accuracy obtained by the ANN network, the proposed method has been compared with the ANN output results presented in Chine et al. [27] and Dhimish et al. [19]. The output confusion matrix for all obtained studies is compared in: Fig. 10 (b), Fig. 14, and Fig. 12 (b), Fig. 15 (a), Fig. 15 (b). As can be noticed, the overall detection efficiency of the proposed ANN network is equal to $94.0 \%$ comparing to $92.1 \%$ by Dhimish et al. [19] in (case 9 faults), and to

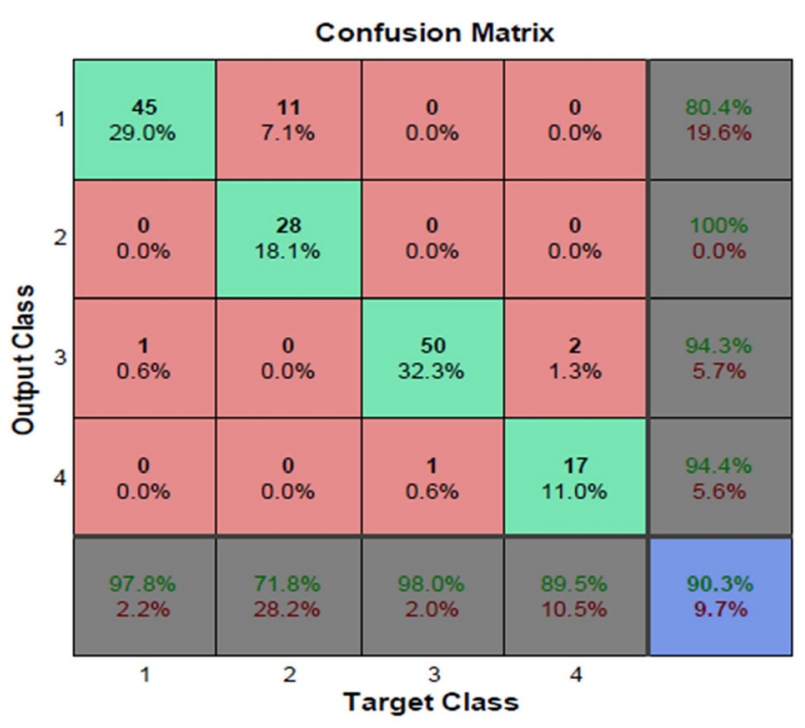

(a)

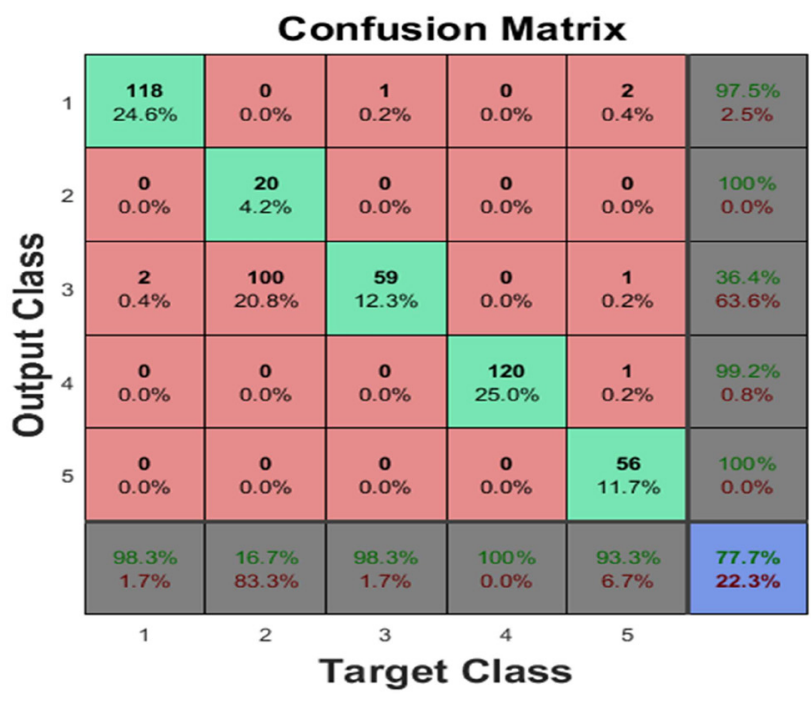

(b)

Fig. 15 Classification Confusion Matrix for ANN Network (case 5 faults). (a) Results obtained by Dhimish et al. [19], (b) Chine et al. [27]

$97.2 \%$ comparing to $90.3 \%$ obtained by Chine et al. [27] and to $77.7 \%$ by Dhimish et al. [19] in (case 4 faults).

\section{Conclusions}

In this work, a simulation study is carried out for diagnosis and detection nine types of defects in a PV module, by two methods, the first one is the thresholding method (classical) and the second one is sophisticated intelligent method by the artificial intelligent networks ANN.

After analyzing the simulation results, it can be observed that the threshold method has several disadvantages and it is difficult because several values of the 
modified parameters of a fault can appear in another fault, which leads to false alarms with the absence of the fault. Although all studied styles for this method have been used to avoid false alarms, but these warnings have appeared and cannot identify the type of fault.

On the other hand, the artificial neural network method proved that it is the most adapted technique (simple and easy) to the diagnosis of PV module defects compared to the method of thresholding. It has been proved that the studied method can accurately detect, via the database,

\section{References}

[1] Kahoul, N., Mekki, M. "Adaptive P\&O MPPT Technique for Photovoltaic Buck- Boost Converter System", International Journal of Computer Applications (0975-8887), 112(12), pp. 23-27, 2015.

[2] IEA PVPS "2019 A snapshot of global Photovoltaic Markets", [online] Available at: http://www.iea-pvps.org [Accessed: 15 April 2019]

[3] Taylor, M., Ralon, P., Ilas, A. "The Power to Change: Solar and Wind Cost Reduction Potential to 2025", International Renewable Energy Agency (IRENA), Abu Dhabi, United Arab Emirates, 2016. [online] Available at: http://www.irena.org/ [Accessed: 01 June 2016]

[4] Mellit, A., Tina, G. M., Kalogirou, S. A. "Fault detection and diagnosis methods for photovoltaic systems: A review", Renewable and Sustainable Energy Reviews, 91, pp. 1-17, 2018.

https://doi.org/10.1016/j.rser.2018.03.062

[5] Tadj, M., Benmouiza, K., Cheknane, A., Silvestre, S. "Improving the performance of PV systems by faults detection using GISTEL approach", Energy Conversion and Management, 80, pp. 298-304, 2014.

https://doi.org/10.1016/j.enconman.2014.01.030

[6] Mellit, A., Pavan, A. M. "A 24-h forecast of solar irradiance using artificial neural network: Application for performance prediction of a grid-connected PV plant at Trieste, Italy", Solar Energy, 84(5), pp. 807-821, 2010.

https://doi.org/10.1016/j.solener.2010.02.006

[7] Takashima, T., Yamaguchi, J., Otani, K., Oozeki, T., Kato, K., Ishida, M. "Experimental studies of fault location in PV module strings", Solar Energy Materials and Solar Cells, 93(6-7), pp. 1079-1082, 2009.

https://doi.org/10.1016/j.solmat.2008.11.060

[8] Kim, K. A., Seo, G. S., Cho, B. H., Krein, P. T. "Photovoltaic HotSpot Detection for Solar Panel Substrings Using AC Parameter Characterization", IEEE Transactions On Power Electronics, 31(2), pp. 1121-1130, 2016.

https://oi.org/10.1109/tpel.2015.2417548

[9] Obi, M., Bass, R. "Trends and challenges of grid-connected photovoltaic systems-A review", Renewable and Sustainable Energy Reviews, 58, pp. 1082-1094, 2016.

https://doi.org/10.1016/j.rser.2015.12.289

[10] Khamis, A., Shareef, H., Bizkevelci, E., Khatib, T. "A review of islanding detection techniques for renewable distributed generation systems", Renewable and Sustainable Energy Reviews, 28, pp. 483-493, 2013.

https://doi.org/10.1016/j.rser.2013.08.025 the different types of defects, based on the database of voltage, current and power. The developed artificial neural network requires a large database and periodic training to evaluate the output parameters with good accuracy. The methodology can be generalized to photovoltaic installations connected to the grid or for large-scale photovoltaic plants as well as for other PV technologies.

In the future, the detection and diagnostic capacity of large-scale system experimentally in real time can be studied.

[11] Dhimish, M., Holmes, V., Mehrdadi, B., Dales, M. "The impact of cracks on photovoltaic power performance", Journal of Science: Advanced Materials and Devices, 2(2), pp. 199-209, 2017. https://doi.org/10.1016/j.jsamd.2017.05.005

[12] Zhao, Y., Yang, L., Lehman, B., de Palma, J. F., Mosesian, J., Lyons, R. "Decision tree-based fault detection and classification in solar photovoltaic arrays", In: 2012 Twenty-Seventh Annual IEEE Applied Power Electronics Conference and Exposition (APEC), Orlando, FL, USA, 2012, pp. 93-99. https://doi.org/10.1109/apec.2012.6165803

[13] Jamshidpour, E., Poure, P., Saadate, S. "Photovoltaic Systems Reliability Improvement by Real555 Time FPGA-Based Switch Failure Diagnosis and Fault-Tolerant DC-DC Converter", IEEE Transactions on Industrial Electronics, 62(11), pp. 7247-7255, 2015. https://doi.org/10.1109/tie.2015.2421880

[14] Chong, B. V. P., Zhang, L. "Controller design for integrated PV-converter modules under partial shading conditions", Solar Energy, 92, pp. 123-138, 2013. https://doi.org/10.1016/j.solener.2013.01.025

[15] Chine, W., Mellit, A., Massi Pavan, A., Kalogirou, S. A. "Fault detection method for grid-connected photovoltaic plants", Renewable Energy, 66, pp. 99-110, 2014. https://doi.org/10.1016/j.renene.2013.11.073

[16] Dhimish, M., Holmes, V. "Fault detection algorithm for grid-connected photovoltaic plants", Solar Energy, 137, pp. 236-245, 2016. https://doi.org/10.1016/j.solener.2016.08.021

[17] Dhimish, M., Holmes, V., Mehrdadi, B., Dales, M. "Simultaneous fault detection algorithm for grid-connected photovoltaic plants", IET Renewable Power Generation, 11(12), pp. 1565-1575, 2017. https://doi.org/10.1049/iet-rpg.2017.0129

[18] Silvestre, S., Aires da Silva, M., Chouder, A., Guasch, D., Karatepe, E. "New procedure for fault detection in grid connected PV systems based on the evaluation of current and voltage indicators", Energy Conversion and Management, 86, pp. 241-249, 2014. https://doi.org/10.1016/j.enconman.2014.05.008

[19] Dhimish, M., Holmes, V., Mehrdadi, B, Dales, M. "Comparing Mamdani Sugeno fuzzy logic and RBF ANN network for PV fault detection", Renewable Energy, 117, pp. 257-274, 2018. https://doi.org/10.1016/j.renene.2017.10.066

[20] Boukenoui, R., Salhi, H., Bradai, R., Mellit, A. "A new intelligent MPPT method for stand-alone photovoltaic systems operating under fast transient variations of shading patterns", Solar Energy, 124, pp. 124-142, 2016. https://doi.org/10.1016/j.solener.2015.11.023 
[21] Mutlag, A. H., Shareef, H., Mohamed, A., Hannan, M. A., Abd Ali, J. "An Improved Fuzzy Logic Controller Design for PV Inverters Utilizing Differential Search Optimization", International Journal of Photoenergy, 2014, Article ID: 469313, 2014. https://doi.org/10.1155/2014/469313

[22] Sa-ngawong, N., Ngamroo, I. "Intelligent photovoltaic farms for robust frequency stabilization in multi-area interconnected power system based on PSO-based optimal Sugeno fuzzy logic control", Renewable Energy, 74, pp. 555-567, 2015. https://doi.org/10.1016/j.renene.2014.08.057

[23] Palaniswamy, A. M., Srinivasan, K. "Takagi-Sugeno fuzzy approach for power optimization in standalone photovoltaic systems", Solar Energy, 139, pp. 213-220, 2016. https://doi.org/10.1016/j.solener.2016.09.027

[24] Dhimish, M., Holmes, V., Mehrdadi, B., Dales, M. "Diagnostic method for photovoltaic systems based on six layer detection algorithm", Electric Power Systems Research, 151, pp. 26-39, 2017. https://doi.org/10.1016/j.epsr.2017.05.024

[25] Dhimish, M., Holmes, V., Mehrdadi, B., Dales, M. "Multi-Layer Photovoltaic Fault Detection Algorithm", High Voltage, 2(4), pp. 244-252, 2017.

https://doi.org/10.1049/hve.2017.0044

[26] Yagi, Y., Kishi, H., Hagihara, R., Tanaka, T., Kozuma, S., Ishida, T., Waki, M., Tanaka, M., Kiyama, S. "Diagnostic technology and an expert system for photovoltaic systems using the learning method", Solar Energy Materials and Solar Cells, 75(3-4), pp. 655-663, 2003. https://doi.org/10.1016/s0927-0248(02)00149-6

[27] Chine, W., Mellit, A., Lughi, V., Malek, A., Sulligoi, G., Massi Pavan, A. "A novel fault diagnosis technique for photovoltaic systems based on artificial neural networks", Renewable Energy, 90, pp. 501-512, 2016.

https://doi.org/10.1016/j.renene.2016.01.036

[28] Mellit, A., Sağlam, S., Kalogirou, S. A. "Artificial neural network-based model for estimating the produced power of a photovoltaic module", Renewable Energy, 60, pp. 71-78, 2013. https://doi.org/10.1016/j.renene.2013.04.011

[29] Olivencia Polo, F. A., Ferrero Bermejo, J., Gómez Fernández, J. F., Crespo Márquez, A. "Failure mode prediction and energy forecasting of PV plants to assist dynamic maintenance tasks by ANN based models", Renewable Energy, 81, pp. 227-238, 2015. https://doi.org/10.1016/j.renene.2015.03.023

[30] Sepasi, S., Reihani, E., Howlader, A. M., Roose, L. R., Matsuura, M. M. "Very short term load forecasting of a distribution system with high PV penetration", Renewable Energy, 106, pp. 142-148, 2017.

https://doi.org/10.1016/j.renene.2017.01.019

[31] Amrouche, B., Le Pivert, X. "Artificial neural network based daily local forecasting for global solar radiation", Applied Energy, 130, pp. 333-341, 2014.

https://doi.org/10.1016/j.apenergy.2014.05.055

[32] Djalab, A., Rezaoui, M. M., Teta, A., Boudiaf, M. "Analysis of MPPT Methods: P \& O, INC and Fuzzy Logic (CLF) for a PV System", In: 2018 6th International Conference on Control Engineering \& Information Technology (CEIT), Istanbul, Turkey, 2018, pp. 1-6. https://doi.org/10.1109/ceit.2018.8751820
[33] Sera, D., Baghzouz, Y. "On the Impact of Partial Shading on PV Output Power", In: 2nd WSEAS/IASME International Conference on RENEWABLE ENERGY SOURCES (RES'08), Corfu, Greece, 2008, pp. 229-234.

[34] Khemliche, M., Djeriou, S., Latreche, S. "Diagnostic de Défauts dans le Système Photovoltaïque par les réseaux de Neurones Artificiels" (Diagnosis of Faults in the Photovoltaic System by Artificial Neural Networks), Revue des Energies Renouvelables SIENR'12 Ghardaïa, pp. 331-343, 2012. (in French)

[35] Garoudja, E., Harrou, F., Sun, Y., Kara, K., Chouder, A., Silvestre, S. "Statistical fault detection in photovoltaic systems", Solar Energy, 150, pp. 485-499, 2017.

https://doi.org/10.1016/j.solener.2017.04.043

[36] Ahadi, A., Miryousefi Aval, S. M., Hayati, H. "Generating capacity adequacy evaluation of large-scale, grid-connected photovoltaic systems", Frontiers in Energy, 10(3), pp. 308-318, 2016. https://doi.org/10.1007/s11708-016-0415-9

[37] Dhimish, M., Holmes, V., Mehrdadi, B., Dales, M., Mather, P. "Detecting Defective Bypass Diodes in Photovoltaic Modules using Mamdani Fuzzy Logic System", Global Journal of Researches in Engineering: Electrical and Electronics Engineering, 17(5), 2017, pp. 32-44.

[38] KC130GHT-2. "High Efficiency Polycrystalline Photovoltaic Module", [online] Available at: www.accuplus/noord.nl/pdf/ KC130GHT-2.pdf [Accessed: (01 April 2013)]

[39] Zhao, Y. "Fault Detection, Classification and Protection in Solar Photovoltaic Arrays", PhD Thesis, Northeastern University. [online] Available at: http://hdl.handle.net/2047/D20195700 [Accessed: 10 January 2016]

[40] International Electrotechnical Commission "IEC 61724 Photovoltaic System Performance Monitoring-Guidelines for Measurement, Data Exchange and Analysis", In: International Standard IEC 61724, Geneva, Italy, 1998. https://doi.org/10.3403/01549027u

[41] Bun, L. "Détection et Localisation de Défauts pour un Système PV" (Faults Detection and Isolation in a PV System), PhD Thesis, Université de Grenoble, 2011. [online] Available at : http://www. theses.fr/2011GRENT11 [Accessed: 01 December 2011] (in French)

[42] Li, Z., Wang, Y., Zhou, D., Wu, C. "An Intelligent Method for Fault Diagnosis in Photovoltaic Array", In: Xiao, T., Zhang, L., Ma, S. (eds) System Simulation and Scientific Computing ICSC 2012: Communications in Computer and Information Science, Springer, Berlin, Heidelberg, Germany, 327, pp. 10-16, 2012.

https://doi.org/10.1007/978-3-642-34396-4_2

[43] Sabri, N., Tlemçani, A., Chouder, A. "Intelligent fault supervisory system applied on stand-alone photovoltaic system", In: 2018 International Conference on Applied Smart Systems (ICASS), Medea, Algeria, 2018, pp. 1-5.

https://doi.org/10.1109/icass.2018.8651950 